\title{
Sol-Gel Synthesis of Silicon-Doped Lithium Manganese Oxide with Enhanced Reversible Capacity and Cycling Stability
}

\author{
Hongyuan Zhao ${ }^{1,2, *}$, Dongdong $\mathrm{Li}^{2}$, Yashuang Wang ${ }^{2}$, Fang $\mathrm{Li}^{2}$, Guifang Wang ${ }^{3, *}$, \\ Tingting $\mathrm{Wu}^{1,2}{ }^{1 D}$, Zhankui Wang ${ }^{1}$, Yongfeng $\mathrm{Li}^{1}$ and Jianxiu $\mathrm{Su}^{1, *}$ \\ 1 School of Mechanical \& Electrical Engineering, Henan Institute of Science and Technology, \\ Xinxiang 453003, China; wtingtingwu@163.com (T.W.); luckywzk@126.com (Z.W.); \\ yongfengli121@outlook.com (Y.L.) \\ 2 Research Branch of Advanced Materials \& Green Energy, Henan Institute of Science and Technology, \\ Xinxiang 453003, China; Lidongdong1994@126.com (D.L.); yashuangwang1102@126.com (Y.W.); \\ lifang@hist.edu.cn (F.L.) \\ 3 School of Resources, Environment and Materials, Guangxi University, Nanning 530004, China \\ * Correspondence: hyzhao@hist.edu.cn (H.Z.); wangguifang66@163.com (G.W.); jxsu2003@hist.edu.cn (J.S.); \\ Tel.: +86-182-3613-1721 (H.Z.)
}

Received: 12 July 2018; Accepted: 14 August 2018; Published: 15 August 2018

\begin{abstract}
A series of silicon-doped lithium manganese oxides were obtained via a sol-gel process. XRD characterization results indicate that the silicon-doped samples retain the spinel structure of $\mathrm{LiMn}_{2} \mathrm{O}_{4}$. Electrochemical tests show that introducing silicon ions into the spinel structure can have a great effect on reversible capacity and cycling stability. When cycled at $0.5 \mathrm{C}$, the optimal Si-doped $\mathrm{LiMn}_{2} \mathrm{O}_{4}$ can exhibit a pretty high initial capacity of $140.8 \mathrm{mAh} \mathrm{g}^{-1}$ with excellent retention of $91.1 \%$ after 100 cycles, which is higher than that of the $\mathrm{LiMn}_{2} \mathrm{O}_{4}, \mathrm{LiMn}_{1.975} \mathrm{Si}_{0.025} \mathrm{O}_{4}$, and $\mathrm{LiMn}_{1.925} \mathrm{Si}_{0.075} \mathrm{O}_{4}$ samples. Moreover, the optimal Si-doped $\mathrm{LiMn}_{2} \mathrm{O}_{4}$ can exhibit $88.3 \mathrm{mAh} \mathrm{g}^{-1}$ with satisfactory cycling performance at $10 \mathrm{C}$. These satisfactory results are mainly contributed by the more regular and increased $\mathrm{MnO}_{6}$ octahedra and even size distribution in the silicon-doped samples obtained by sol-gel technology.
\end{abstract}

Keywords: lithium-ion batteries; $\mathrm{LiMn}_{2} \mathrm{O}_{4}$; sol-gel method; Si-doping; electrochemical properties

\section{Introduction}

As green energy, the application of lithium-ion batteries has been extended to various fields in our life [1-3]. At present, an increasing number of countries are publishing timetables and road maps for forbidding the sale of traditional fuel vehicles. Against this backdrop, the research and development of lithium-ion batteries is receiving more and more attention at home and abroad. It is generally known that the cathode materials greatly influence the electrochemical performance of lithium-ion batteries. Among appropriate cathode materials, $\mathrm{LiMn}_{2} \mathrm{O}_{4}$ possesses the distinct advantages of low price, mature production technology and non-pollution characteristic, and is conducive to sustainable development and large-scale application [4,5]. However, it is a great pity that the poor cycling life cannot satisfy the needs of commercial application of $\mathrm{LiMn}_{2} \mathrm{O}_{4}$. This unwelcome fact is related to Jahn-Teller distortion, manganese dissolution and non-uniform particle-size distribution [6-8].

Until now, a large number of optimization strategies have been developed to enhance the electrochemical performance of $\mathrm{LiMn}_{2} \mathrm{O}_{4}$ [7,9-14]. According to the reported works [7,15], the surface coating treatment can improve the cycling performance to some degree by inhibiting the dissolution of manganese in the electrolyte. Unfortunately, this strategy cannot fundamentally reduce the 
negative impacts of the Jahn-Teller distortion effect, and also decreases the discharge capacity [12]. These facts indicate that surface modification is not a top-priority optimization method to enhance the comprehensive performance of $\mathrm{LiMn}_{2} \mathrm{O}_{4}$. Therefore, lots of researchers choose to use the doping strategy to avoid the shortcoming of the surface coating treatment $[11,16,17]$. Yu et al. [17] prepared $\mathrm{Li}_{1+\mathrm{x}} \mathrm{Mn}_{2-\mathrm{x}} \mathrm{O}_{4}$ samples by a solid-state sintering method. The obtained $\mathrm{Li}_{1.06} \mathrm{Mn}_{1.94} \mathrm{O}_{4}$ sample presents better cycling performance because the introduction of lithium ions can weaken the ordering of lithium ions and enhance the structure stability. Xu et al. [18] reported the synthesis of $\mathrm{LiZn}_{\mathrm{x}} \mathrm{Mn}_{2-\mathrm{x}} \mathrm{O}_{4}$ by a solution combustion method. The research results showed that $\mathrm{Zn}$-doping can enhance the cycling performance by reducing the negative impacts of the Jahn-Teller distortion effect. Furthermore, the $\mathrm{LiAl}_{x} \mathrm{Mn}_{2-x} \mathrm{O}_{4}$ samples synthesized by solution combustion technique present better cycling life, which benefits from the effective inhibition of the Jahn-Teller distortion by Al-doping [19]. These analyses indicate that introducing other cations can actually enhance the cycling life of $\mathrm{LiMn}_{2} \mathrm{O}_{4}$. It should be noted, however, that introducing some monovalent cations, bivalent cations or trivalent cations can produce certain negative effects on reversible capacity because of the decrease of $\mathrm{Mn}^{3+}$ ions, which has previously been confirmed [11,20-22]. Based on all of the above studies, the introduction of some tetravalent cations has been proposed to effectively enhance the electrochemical performance of $\mathrm{LiMn}_{2} \mathrm{O}_{4}$ because this modification strategy can avoid the decrease of $\mathrm{Mn}^{3+}$ ions [23,24].

Herein, we have successfully obtained a series of silicon-doped lithium manganese oxides $\left(\mathrm{LiMn}_{2-x} \mathrm{Si}_{\mathrm{x}} \mathrm{O}_{4}, \mathrm{x} \leq 0.10\right)$ by sol-gel technology. The effect of silicon doping content on the structures, morphologies and electrochemical properties of the $\mathrm{LiMn}_{2-x} \mathrm{Si}_{x} \mathrm{O}_{4}$ samples obtained by sol-gel technology is discussed. The results indicate that the optimal silicon-doped sample prepared by sol-gel technology shows pretty high reversible capacity and outstanding cycling life.

\section{Materials and Methods}

The silicon-doped lithium manganese oxides $\left(\mathrm{LiMn}_{2-x} \mathrm{Si}_{x} \mathrm{O}_{4}, \mathrm{x} \leq 0.10\right)$ were obtained via a sol-gel process with tetraethoxysilane (TEOS, Sinopharm Chemical Reagent Co., Ltd., Shanghai, China) as the dopant. Firstly, stoichiometric lithium hydroxide $(0.8812 \mathrm{~g})$ and citric acid $(4.4129 \mathrm{~g})$ were dissolved in deionized water $(20 \mathrm{~mL})$. Under vigorous stirring, the manganese acetate solution $(1.5 \mathrm{M})$ and mixed solution of TEOS $(0.2083 \mathrm{~g})$ and ethanol solution $(3.0 \mathrm{~mL})$ were added dropwise into the above-mentioned solution at $50{ }^{\circ} \mathrm{C}$. Then, a certain amount of $\mathrm{NH}_{3} \cdot \mathrm{H}_{2} \mathrm{O}$ (Sinopharm Chemical Reagent Co., Ltd., Shanghai, China) was added dropwise into the mixed solution to adjust the $\mathrm{pH}$ value to $7-8$, and the temperature was adjusted to $70{ }^{\circ} \mathrm{C}$. After continuous stirring for a few hours, a reddish-brown sol was formed, which was then dried at $110^{\circ} \mathrm{C}$. The obtained dried gel was sintered at $450{ }^{\circ} \mathrm{C}$ for $4 \mathrm{~h}$ and then further sintered at $750^{\circ} \mathrm{C}$ for $18 \mathrm{~h}$ at a heating and cooling speed of $5^{\circ} \mathrm{C} \cdot \mathrm{min}^{-1}$. To investigate the influence of the Si-doping, an undoped $\mathrm{LiMn}_{2} \mathrm{O}_{4}$ spinel was prepared under the same conditions.

The crystal structures of the obtained silicon-doped $\mathrm{LiMn}_{2} \mathrm{O}_{4}$ samples were studied by X-ray diffraction technique (XRD, Bruker DX-1000, Karlsruhe, Germany) with $\mathrm{Cu}$ K $\alpha$ radiation $(\lambda=0.15406 \mathrm{~nm})$. Both transmission electron microscopy (TEM, JEOL JEM-3010, Tokyo, Japan) and scanning electron microscopy (SEM, JEOL JSM-6360LV, Tokyo, Japan) analytical techniques were used to study the surface morphologies and microstructures.

The active electrode consisted of the obtained silicon-doped $\mathrm{LiMn}_{2} \mathrm{O}_{4}$ samples, conductive acetylene black and polyvinylidene fluoride (Weight Ratio $=85: 10: 5$ ). The anode material and diaphragm were lithium foil and Celgard 2400 polymer (Charlotte, NA, USA), respectively. The mixture of $1 \mathrm{M} \mathrm{LiPF}_{6}$, ethyl methyl carbonate (EMC), ethylene carbonate (EC) and dimethyl carbonate (DMC) was used as electrolyte (EMC: EC: DMC = 1:1:1) (Guangzhou Tinci Materials Technology Co., Ltd., Guagnzhou, China). The electrochemical measurement was executed on NEWARE battery testing system. The cyclic voltammogram results and electrochemical impedance spectroscopy (EIS) were tested by CS-350 electrochemical workstation (Wuhan Corrtest Instruments Crop., Ltd., Wuhan, China). 


\section{Results and Discussion}

To investigate the influence of Si-doping content on the crystalline phase of $\mathrm{LiMn}_{2} \mathrm{O}_{4}, \mathrm{XRD}$ was performed on the obtained samples. As shown in Figure 1, the characteristic diffraction peaks of all the $\mathrm{Li}_{\mathrm{Mn} 2-x} \mathrm{Si}_{\mathrm{x}} \mathrm{O}_{4}$ samples obtained by sol-gel technology agree with that of $\mathrm{LiMn}_{2} \mathrm{O}_{4}$ (JCPDS No. 35-0782), suggesting the silicon-doped lithium manganese oxides obtained by sol-gel technology possess the cubic spinel structure, with lithium and manganese ions located at tetrahedral sites (8a) and octahedral sites (16d), respectively [25]. In addition, the (220) characteristic diffraction peak will be observed if the tetrahedral sites are occupied by other cations [26]. However, note that the (220) peak does not appear in the XRD patterns of the silicon-doped $\mathrm{LiMn}_{2} \mathrm{O}_{4}$ samples, indicating the substitution of silicon ions for manganese ions.

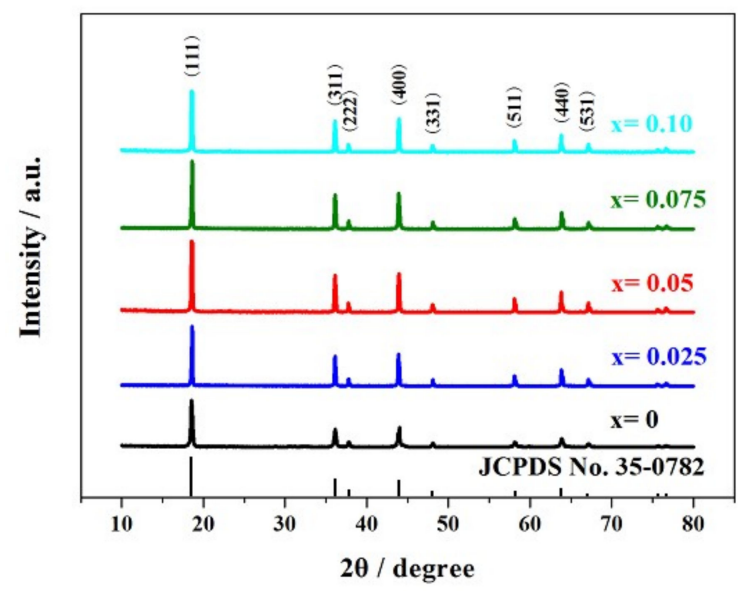

Figure 1. XRD patterns of the $\mathrm{LiSi}_{x} \mathrm{Mn}_{2-\mathrm{x}} \mathrm{O}_{4}(\mathrm{x}=0,0.025,0.05,0.075$ and 0.10$)$ samples.

Table 1 presents the relevant parameters of the $\mathrm{LiMn}_{2-x} \mathrm{Si}_{x} \mathrm{O}_{4}$ samples obtained by sol-gel technology. It is clear from the data that all the $\mathrm{LiMn}_{2-x} \mathrm{Si}_{\mathrm{x}} \mathrm{O}_{4}$ samples belong to $\mathrm{Fd}-3 \mathrm{~m}$ space group. As the silicon doping content increases, the lattice parameter of these samples gradually increases. According to the reported results [24], the silicon-doped spinel presents longer $\mathrm{Mn}-\mathrm{O}$ bond length and larger $\mathrm{MnO}_{6}$ octahedra. Moreover, the $\mathrm{O}-\mathrm{Mn}-\mathrm{O}$ angle in the Si-doped spinel presents values closer to 90 . These results suggest that introducing some silicon ions leads to the more regular and increased $\mathrm{MnO}_{6}$ octahedra, which could explain the increase of lattice parameter and cell volume. In addition, Si-doping showed a great influence on the (400) FWHM value and the (311)/(400) intensity ratio. Among all the silicon-doped spinels, the $\mathrm{LiMn}_{1.95} \mathrm{Si}_{0.05} \mathrm{O}_{4}$ sample shows a smaller (400) FWHM value and (311)/(400) intensity ratio than the other samples, which is consistent with the results of previous research [27], suggesting higher crystallinity and longer cycling life.

Table 1. Crystal parameters of the $\mathrm{LiSi}_{\mathrm{x}} \mathrm{Mn}_{2-\mathrm{x}} \mathrm{O}_{4}(\mathrm{x}=0,0.025,0.05,0.075$ and 0.10$)$ samples.

\begin{tabular}{llcccc}
\hline \multicolumn{1}{c}{ Sample } & Space & $\mathbf{a}(\mathbf{n m})$ & Volume $\left.\mathbf{( n m}^{\mathbf{3}}\right)$ & $\mathbf{I}_{\mathbf{3 1 1}} / \mathbf{I}_{\mathbf{4 0 0}}$ & $\mathbf{F W H M}_{\mathbf{4 0 0}}$ \\
\hline $\mathrm{LiMn}_{2} \mathrm{O}_{4}$ & $\mathrm{Fd}-3 \mathrm{~m}$ & 0.82325 & 0.55795 & 0.8992 & 0.291 \\
$\mathrm{LiSi}_{0.025} \mathrm{Mn}_{1.975} \mathrm{O}_{4}$ & $\mathrm{Fd}-3 \mathrm{~m}$ & 0.82328 & 0.55801 & 0.9274 & 0.278 \\
$\mathrm{LiSi}_{0.05} \mathrm{Mn}_{1.95} \mathrm{O}_{4}$ & $\mathrm{Fd}-3 \mathrm{~m}$ & 0.82335 & 0.55815 & 0.9645 & 0.243 \\
$\mathrm{LiSi}_{0.075} \mathrm{Mn}_{1.925} \mathrm{O}_{4}$ & $\mathrm{Fd}-3 \mathrm{~m}$ & 0.82344 & 0.55834 & 0.9587 & 0.258 \\
$\mathrm{LiSi}_{0.10} \mathrm{Mn}_{1.90} \mathrm{O}_{4}$ & $\mathrm{Fd}-3 \mathrm{~m}$ & 0.82360 & 0.55866 & 0.9453 & 0.265 \\
\hline
\end{tabular}

The SEM images of the $\mathrm{LiMn}_{2-x} \mathrm{Si}_{x} \mathrm{O}_{4}$ samples are shown in Figure 2. The undoped $\mathrm{LiMn}_{2} \mathrm{O}_{4}$ particles shown in Figure 2a present an uneven size distribution. The corresponding range of particle size is from 0.1 to $1.6 \mu \mathrm{m}$. For the Si-doped $\mathrm{LiMn}_{2} \mathrm{O}_{4}$, the introduction of some silicon 
ions can optimize the mean diameter and size distribution. When the silicon doping content increases, the mean diameter of the $\mathrm{LiMn}_{2-\mathrm{x}} \mathrm{Si}_{\mathrm{x}} \mathrm{O}_{4}(0.025 \leq \mathrm{x} \leq 0.10)$ has a decreasing tendency, which may be interpreted as the nucleation rate of silicon-doped samples exceeding the growth of particles with the silicon doping $[5,28]$. In particular, the $\mathrm{LiMn}_{1.95} \mathrm{Si}_{0.05} \mathrm{O}_{4}$ particles shown in Figure 2c present the most uniform size distribution, which is conducive to the enhancement of cycling life [28,29]. The above-mentioned results suggest that introducing some silicon ions can effectively improve the crystallinity and optimize the size distribution. Figure 3a,b shows the TEM and HRTEM images of the representative $\mathrm{LiMn}_{1.95} \mathrm{Si}_{0.05} \mathrm{O}_{4}$ sample. It can be observed that the growth of sample particles matches the (111) direction, and the lattice fringes of $0.478 \mathrm{~nm}$ correspond to the spinel lattice structure [30].
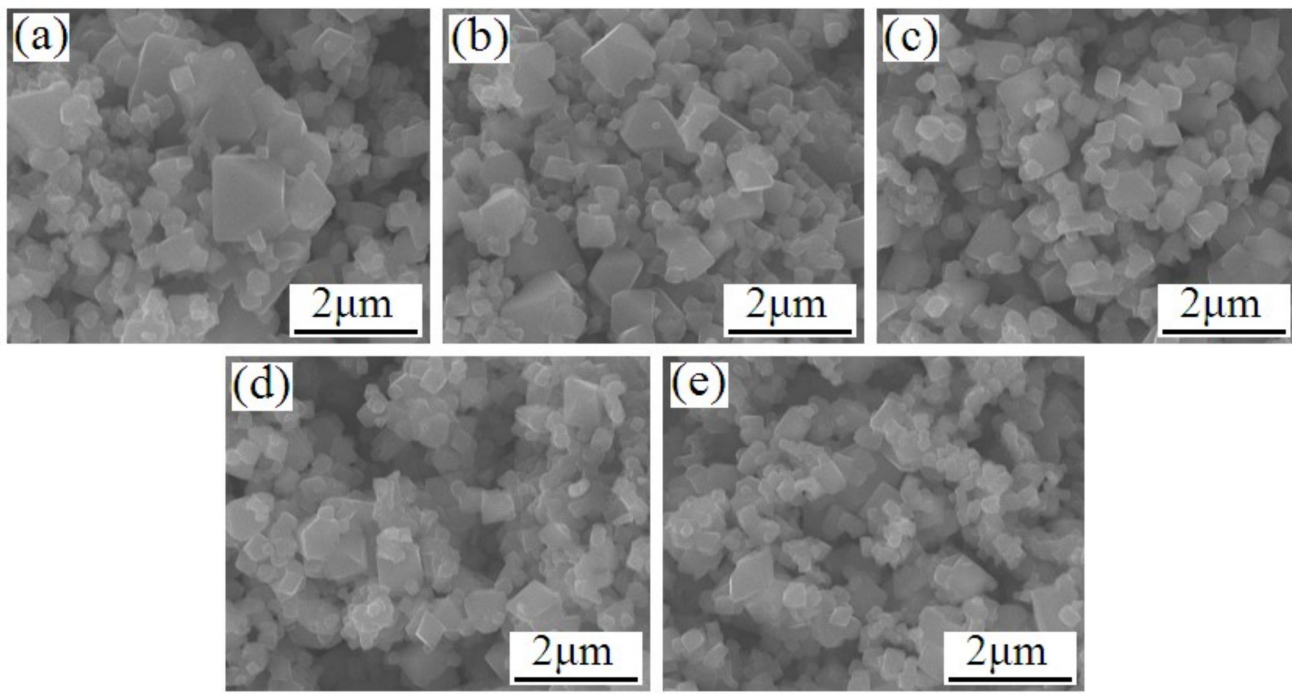

Figure 2. SEM images of the $\mathrm{LiSi}_{x} \mathrm{Mn}_{2-\mathrm{x}} \mathrm{O}_{4}$ samples: $(\mathbf{a}) \mathrm{x}=0,(\mathbf{b}) \mathrm{x}=0.025,(\mathbf{c}) \mathrm{x}=0.05,(\mathbf{d}) \mathrm{x}=0.075$, (e) $\mathrm{x}=0.10$.
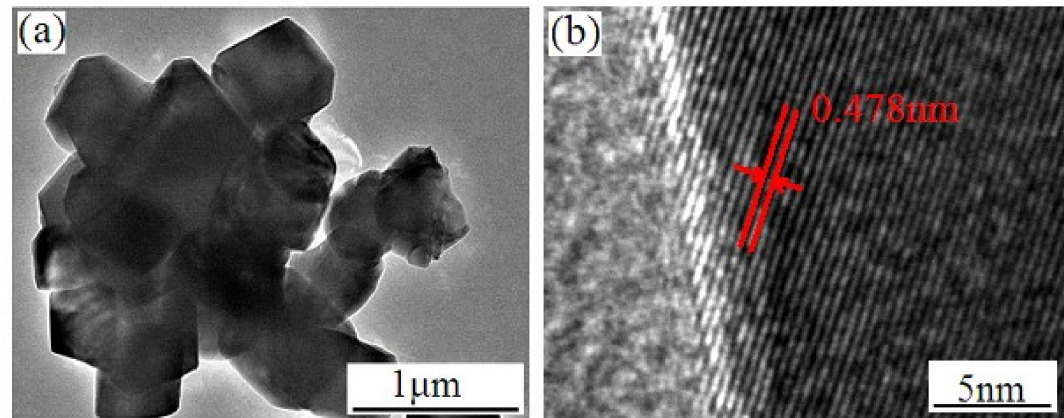

Figure 3. (a) TEM image and (b) HRTEM image of the $\mathrm{LiSi}_{0.05} \mathrm{Mn}_{1.95} \mathrm{O}_{4}$ sample.

The XPS spectra of Li1s, Si2p, Mn2p and O1s in the $\mathrm{LiMn}_{1.95} \mathrm{Si}_{0.05} \mathrm{O}_{4}$ sample are shown in Figure 4. According to these results, we can obtain information regarding the chemical and electronic state. As shown in Figure $4 a, c-d$, the oxidation states of Li1s, Mn2p and O1s can be inferred from the binding energy peaks, which are consistent with the existing results [31]. it is important to note that the binding energies of $\mathrm{Mn} 2 \mathrm{p}_{3 / 2}$ correspond to the $\mathrm{Mn}^{3+}$ ions $(641.7 \mathrm{eV})$ and $\mathrm{Mn}^{4+}$ ions $(643.1 \mathrm{eV})$, respectively [32]. However, the Mn2 $\mathrm{p}_{3 / 2}$ binding energy shown in Figure $4 \mathrm{c}$ is at $642.6 \mathrm{eV}$, suggesting the mixture situation of $\mathrm{Mn}^{3+}$ and $\mathrm{Mn}^{4+}$ in the silicon-doped sample obtained by sol-gel technology. Figure $4 \mathrm{~b}$ presents the XPS spectra of Si2p. We can deduce that the corresponding oxidation state is at $102.1 \mathrm{eV}$, which is in good agreement with the reported results [24]. 

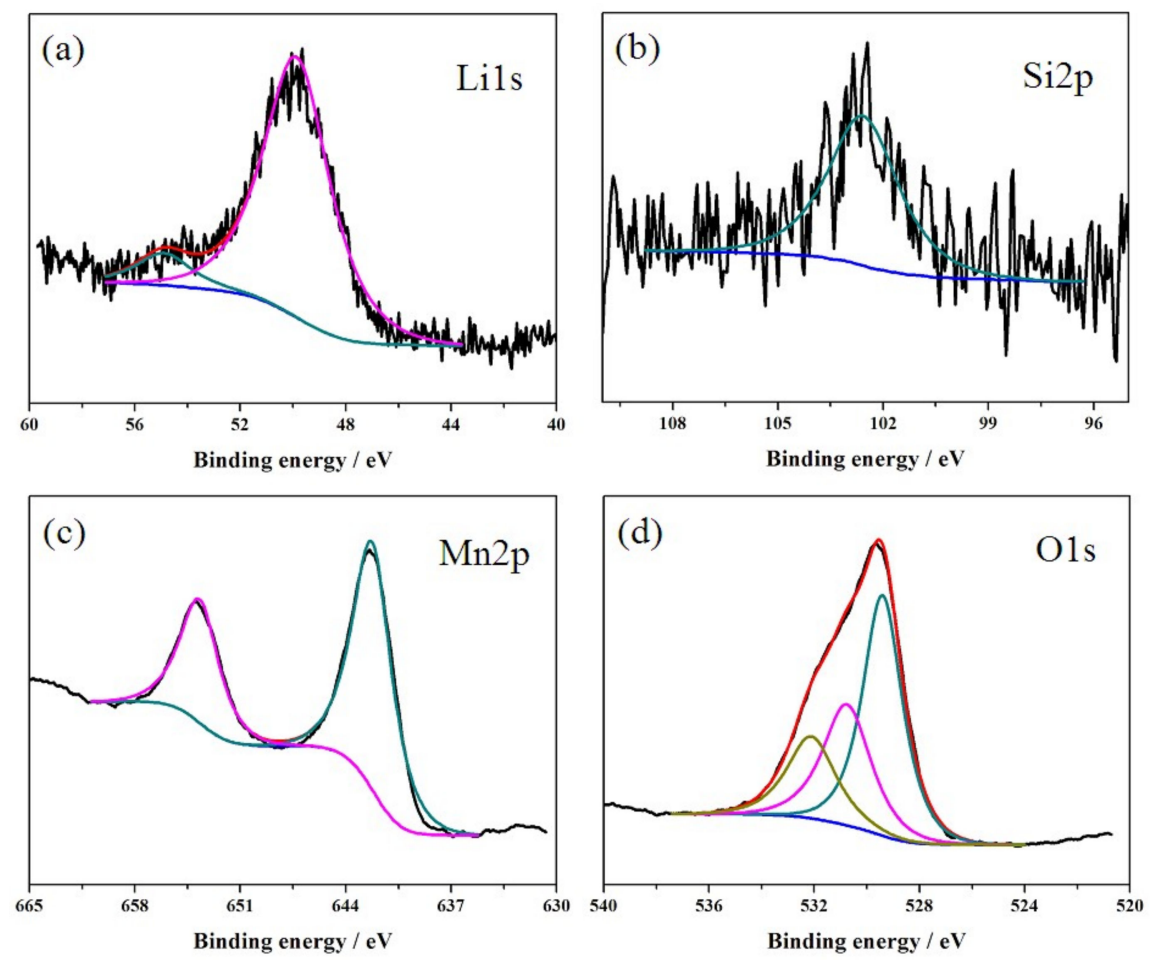

Figure 4. XPS spectra of Li1s (a), Si2p (b), Mn2p (c) and O1s (d) in the $\mathrm{LiSi}_{0.05} \mathrm{Mn}_{1.95} \mathrm{O}_{4}$ sample.

Figure 5a presents the first discharge curves of the $\mathrm{LiMn}_{2-\mathrm{x}} \mathrm{Si}_{\mathrm{x}} \mathrm{O}_{4}(\mathrm{x}=0,0.025,0.05,0.075$ and 0.10) samples. All these silicon-doped samples present characteristic discharge curves, showing two distinct voltage platforms around 4.10-4.15 V and 3.95-4.00 V, suggesting that introducing silicon ions did not change the electrochemical redox reaction mechanism, and that all these Si-doped $\mathrm{LiMn}_{2} \mathrm{O}_{4}$ sample processes comprise two extraction/insertion processes of lithium ions [33]. Figure $5 \mathrm{~b}$ presents the cycling life of the $\mathrm{LiMn}_{2-x} \mathrm{Si}_{\mathrm{x}} \mathrm{O}_{4}(\mathrm{x}=0,0.025,0.05,0.075$ and 0.10$)$ samples. The reversible capacity and cycling life of the $\mathrm{LiMn}_{2-x} \mathrm{Si}_{x} \mathrm{O}_{4}(\mathrm{x}=0,0.025,0.05)$ samples were remarkably enhanced as the silicon doping content increased, due to the more regular and increased $\mathrm{MnO}_{6}$ octahedra, which is conducive to the lithium ion diffusion in the electrochemical redox process [24]. However, it should be noted that the introduction of more silicon ions has great negative impact on the reversible capacities of the $\mathrm{LiMn}_{2-\mathrm{x}} \mathrm{Si}_{\mathrm{x}} \mathrm{O}_{4}(\mathrm{x}=0.075,0.10)$ samples despite the improvement of cycling life (Figure $\left.5 \mathrm{c}\right)$. These unsatisfying results are principally because introducing more silicon ions can cause a reduction in the tetravalent manganese ions, which is unfavorable to $\mathrm{Mn}(\mathrm{III})-\mathrm{Mn}(\mathrm{IV})$ interconversion. When the silicon doping content is 0.075 and 0.10 , the adverse effect exceeds the positive influence from the more regular and increased $\mathrm{MnO}_{6}$ octahedra. Therefore, the electrochemical performance the $\mathrm{LiMn}_{2-x} \mathrm{Si}_{\mathrm{x}} \mathrm{O}_{4}$ $(x=0.075,0.10)$ samples will deteriorate to some extent. 

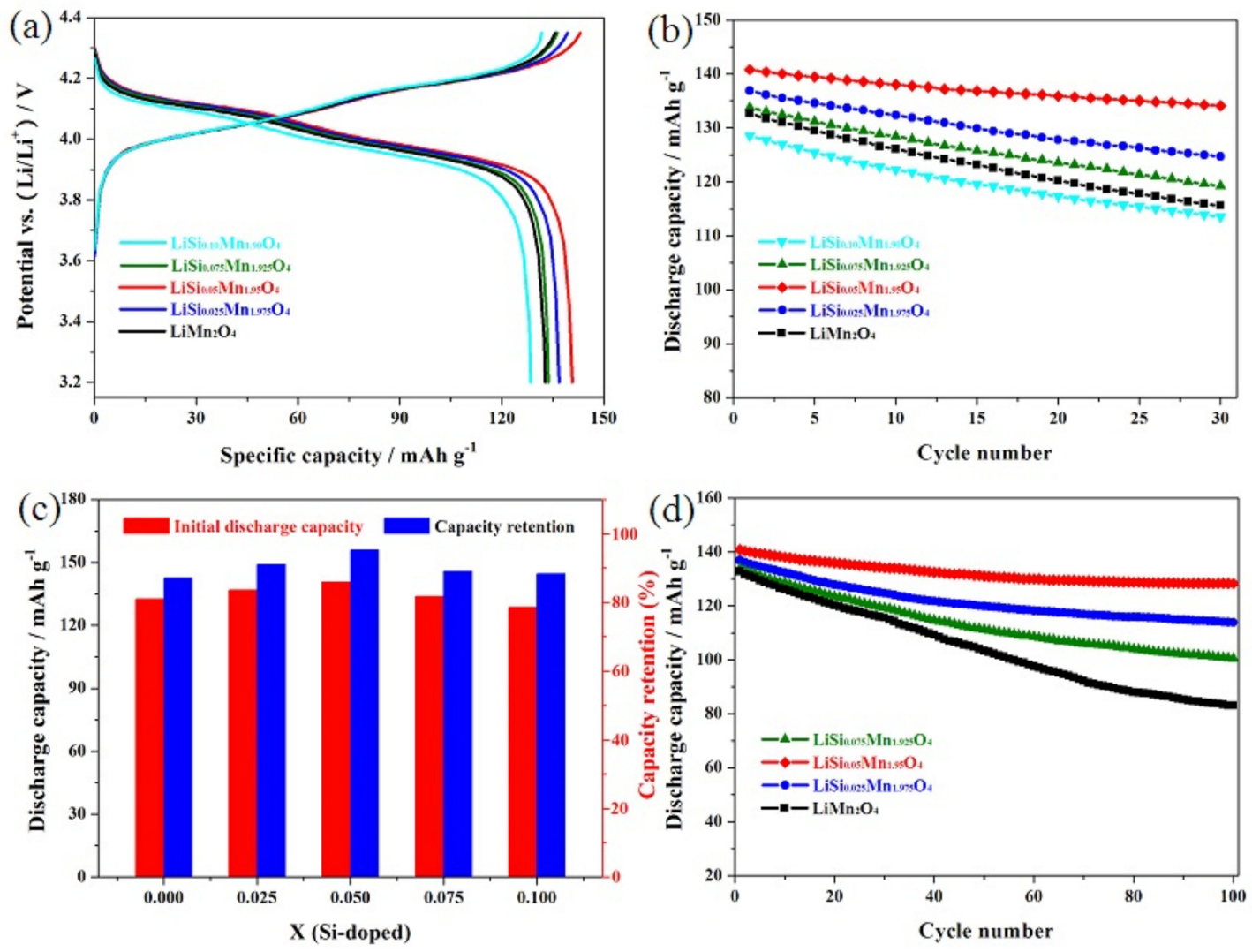

Figure 5. (a) Initial charge-discharge curves and (b) Cycling performance of the $\mathrm{LiSi}_{x} \mathrm{Mn}_{2-\mathrm{x}} \mathrm{O}_{4}(\mathrm{x}=0$, $0.025,0.05,0.075$ and 0.10 ) samples; (c) Comparison plots of the initial discharge capacities and capacity retentions; (d) Long Cycling performance of the $\mathrm{LiSi}_{x} \mathrm{Mn}_{2-\mathrm{x}} \mathrm{O}_{4}(\mathrm{x}=0,0.025,0.05,0.075)$ samples.

Figure $5 \mathrm{~d}$ presents the long cycling life of the $\mathrm{LiMn}_{2-\mathrm{x}} \mathrm{Si}_{\mathrm{x}} \mathrm{O}_{4}(\mathrm{x}=0,0.025,0.05$ and 0.075$)$ samples. For the $\mathrm{LiMn}_{1.95} \mathrm{Si}_{0.05} \mathrm{O}_{4}$ sample, the reversible capacity peaked at $140.8 \mathrm{mAh} \mathrm{g}^{-1}$, which is higher than that of the $\mathrm{LiMn}_{2-\mathrm{x}} \mathrm{Si}_{\mathrm{x}} \mathrm{O}_{4}(\mathrm{x}=0,0.025$ and 0.075$)$ samples. Even more importantly, the $\mathrm{LiMn}_{1.95} \mathrm{Si}_{0.05} \mathrm{O}_{4}$ sample exhibited $128.3 \mathrm{mAh} \mathrm{g}^{-1}$ after 100 cycles, with an outstanding retention of $91.1 \%$. Unfortunately, the $\mathrm{LiMn}_{2-\mathrm{x}} \mathrm{Si}_{\mathrm{x}} \mathrm{O}_{4}(\mathrm{x}=0,0.025$ and 0.075$)$ samples showed a lower capacity with worse cycling life. In particular, the undoped spinel only delivered $132.7 \mathrm{mAh} \mathrm{g}^{-1}$ with low retention of $62.5 \%$ after 100 cycles. These analyses indicate that the introduction of silicon ions dramatically enhances the electrochemical performance of $\mathrm{LiMn}_{2} \mathrm{O}_{4}$.

Figure 6a shows the rate performance of the $\mathrm{LiMn}_{2-x} \mathrm{Si}_{x} \mathrm{O}_{4}(\mathrm{x}=0,0.025,0.05$ and 0.075$)$ samples. For all these samples, the increased rate has a great negative impact on the reversible capacity because the high rate seriously interferes with the diffusion process of lithium ions [26]. Among these samples, the $\mathrm{LiMn}_{1.95} \mathrm{Si}_{0.05} \mathrm{O}_{4}$ sample showed relatively good rate capability with that of the $\mathrm{LiMn}_{2-x} \mathrm{Si}_{x} \mathrm{O}_{4}$ $(x=0,0.025$ and 0.075$)$ samples at a high rate. When cycled at $0.2 \mathrm{C}$, the capacities of the $\mathrm{LiMn}_{2} \mathrm{O}_{4}$, $\mathrm{LiMn}_{1.975} \mathrm{Si}_{0.025} \mathrm{O}_{4}, \mathrm{LiMn}_{1.95} \mathrm{Si}_{0.05} \mathrm{O}_{4}$ and $\mathrm{LiMn}_{1.925} \mathrm{Si}_{0.075} \mathrm{O}_{4}$ samples reached 133.4, 135.9, 139.2 and $142.5 \mathrm{mAh} \cdot \mathrm{g}^{-1}$, respectively. However, it is important to note that the discharge capacities of these Si-doped samples show more and more obvious difference at 5.0 C. The $\mathrm{LiMn}_{1.95} \mathrm{Si}_{0.05} \mathrm{O}_{4}$ sample could show $102.1 \mathrm{mAh} \cdot \mathrm{g}^{-1}$, while the $\mathrm{LiMn}_{2} \mathrm{O}_{4}, \mathrm{LiMn}_{1.975} \mathrm{Si}_{0.025} \mathrm{O}_{4}$ and $\mathrm{LiMn}_{1.925} \mathrm{Si}_{0.075} \mathrm{O}_{4}$ samples showed lower discharge capacities of $62.8,72.8$ and $87.7 \mathrm{mAh} \cdot \mathrm{g}^{-1}$. The above discussion indicates that the optimal Si-doping amount can produce the best improvement effect on the electrochemical performance on the premise that all the silicon-doped samples involved a small amount of $\mathrm{Si}^{4+}$ ions.

To further explore the rate performance at high rates, the $\mathrm{LiMn}_{2-x} \mathrm{Si}_{x} \mathrm{O}_{4}(\mathrm{x}=0,0.025,0.05$ and 0.075 ) samples were tested at $10 \mathrm{C}$, and the corresponding test results are presented in Figure $6 \mathrm{~b}$. For the $\mathrm{LiSi}_{0.05} \mathrm{Mn}_{1.95} \mathrm{O}_{4}$ sample, the reversible capacity of the first cycle could exhibit $88.3 \mathrm{mAh} \cdot \mathrm{g}^{-1}$, 
which is much higher than that of the $\mathrm{LiMn}_{2} \mathrm{O}_{4}, \mathrm{LiMn}_{1.975} \mathrm{Si}_{0.025} \mathrm{O}_{4}$ and $\mathrm{LiMn}_{1.925} \mathrm{Si}_{0.075} \mathrm{O}_{4}$ samples. Moreover, the $\mathrm{LiMn}_{1.95} \mathrm{Si}_{0.05} \mathrm{O}_{4}$ sample showed a satisfactory reversible capacity of $80.4 \mathrm{mAh} \cdot \mathrm{g}^{-1}$ after 30 cycles with an outstanding retention of $91.2 \%$. For the $\mathrm{LiMn}_{2-\mathrm{x}} \mathrm{Si}_{\mathrm{x}} \mathrm{O}_{4}(\mathrm{x}=0,0.025$ and 0.075$)$ samples, a lower reversible capacity with worse cycling stability was presented. The above results further confirmed that the best improvement effect was obtained by introducing an optimal amount of $\mathrm{Si}^{4+}$ ions.

Figure $6 c, d$ present the representative discharge curves of the undoped $\mathrm{LiMn}_{2} \mathrm{O}_{4}$ and the $\mathrm{LiMn}_{1.95} \mathrm{Si}_{0.05} \mathrm{O}_{4}$ samples at varying rates. As shown here, there are two obvious voltage platforms at $0.2 \mathrm{C}$ and $0.5 \mathrm{C}$, suggesting the diffusion process of lithium ions [33]. When the rate was further increased, these two potential plateaus gradually show ambiguous boundaries and shift toward lower voltage as the discharge rate increases. This result has a lot to do with the ohmic drop and the polarization effect [9]. Compared with the $\mathrm{LiMn}_{1.95} \mathrm{Si}_{0.05} \mathrm{O}_{4}$ sample, the undoped $\mathrm{LiMn}_{2} \mathrm{O}_{4}$ sample showed a lower platform at high rate and a more obvious reduction in capacity. The above analysis indicates that the introduction of some silicon ions can have a positive effect on high rate performance.
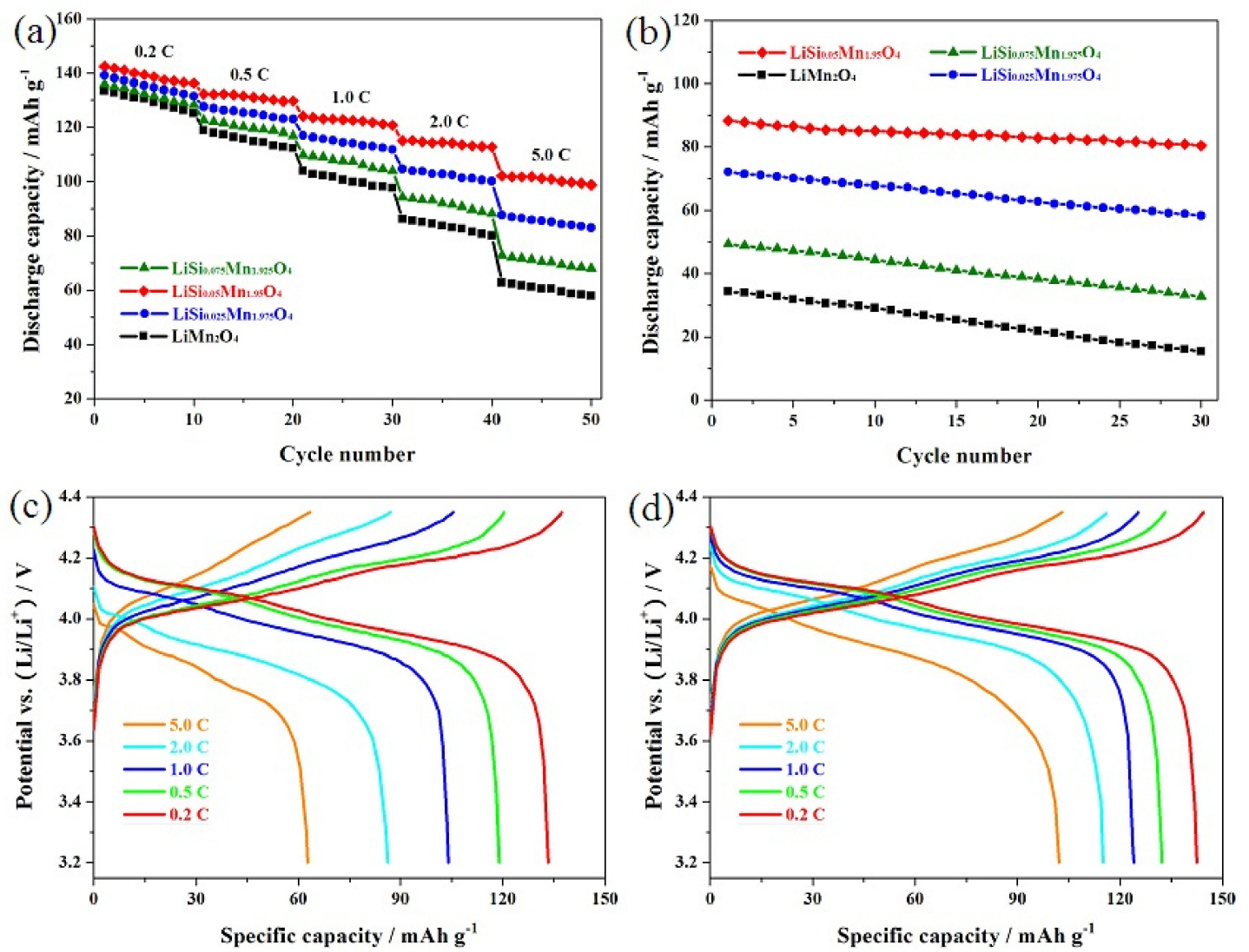

Figure 6. (a) Rate performance of the $\mathrm{LiSi}_{x} \mathrm{Mn}_{2-\mathrm{x}} \mathrm{O}_{4}(\mathrm{x}=0,0.025,0.05,0.075)$ samples; (b) Cycling performance of the $\mathrm{LiSi}_{x} \mathrm{Mn}_{2-\mathrm{x}} \mathrm{O}_{4}(\mathrm{x}=0,0.025,0.05,0.075)$ samples at the higher discharge rate of $10 \mathrm{C}$; Representative charge-discharge curves of the $\mathrm{LiMn}_{2} \mathrm{O}_{4}$ (c) and $\mathrm{LiSi}_{0.05} \mathrm{Mn}_{1.95} \mathrm{O}_{4}$ (d) samples at varying rates of $0.2-5.0 \mathrm{C}$.

Figure $7 \mathrm{a}, \mathrm{b}$ show the cyclic voltammogram results of the undoped $\mathrm{LiMn}_{2} \mathrm{O}_{4}$ and the $\mathrm{LiMn}_{1.95} \mathrm{Si}_{0.05} \mathrm{O}_{4}$ samples. As shown in Figure $7 \mathrm{a}$, the undoped $\mathrm{LiMn}_{2} \mathrm{O}_{4}$ possesses two pairs of redox peaks, which correspond to the relevant diffusion process of lithium ions [34]. It is important to note that the redox peak current decreased significantly after 100 cycles, suggesting that the undoped $\mathrm{LiMn}_{2} \mathrm{O}_{4}$ sample did not show outstanding cycling performance [35]. Figure $7 \mathrm{~b}$ presents the results of the $\mathrm{LiMn}_{1.95} \mathrm{Si}_{0.05} \mathrm{O}_{4}$ sample. We can see that there are few significant changes in the peak currents. 
These results suggest that the introduction of some silicon ions plays an effective role in enhancing lithium ion diffusion.
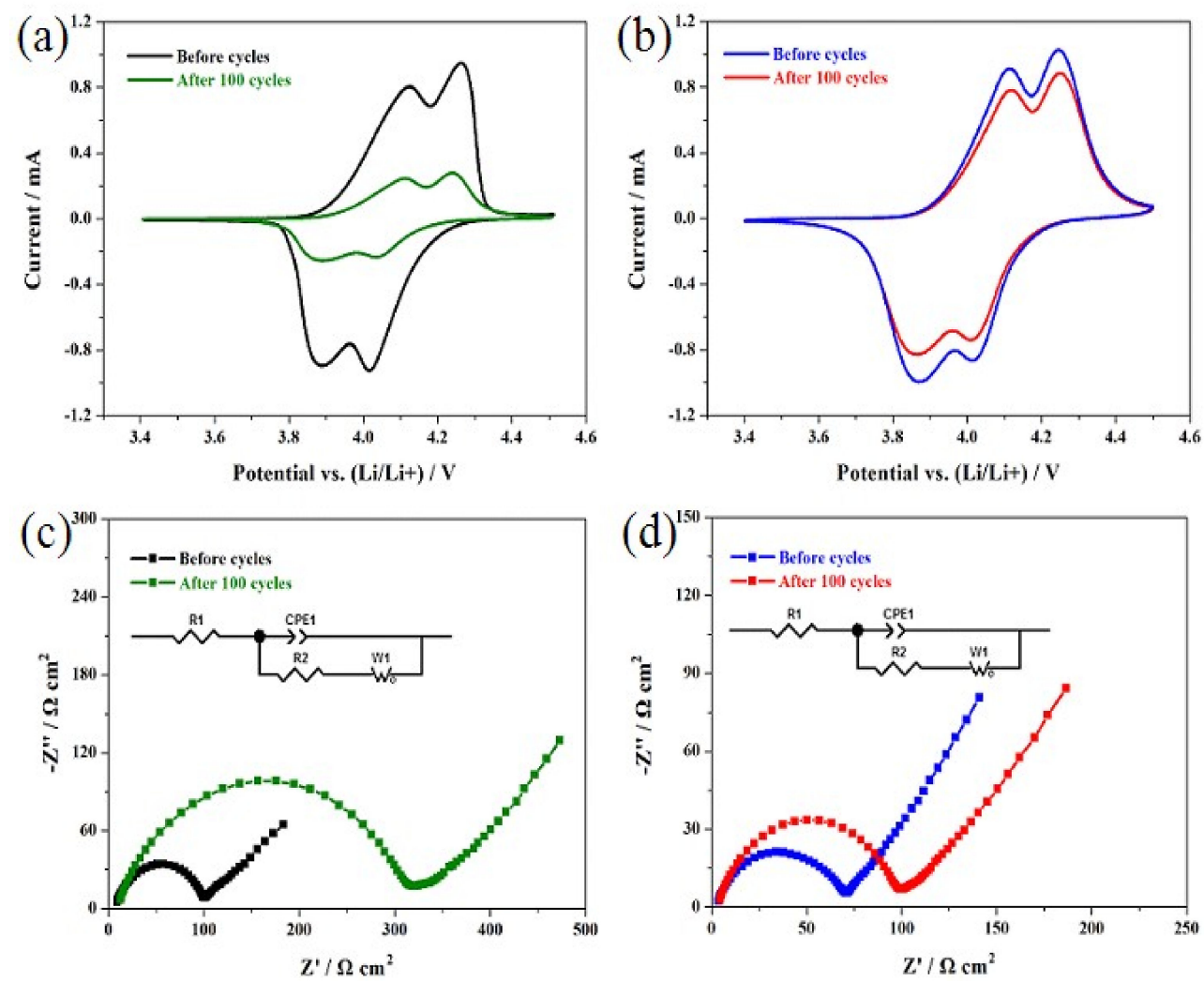

Figure 7. Cyclic voltammogram curves of the $\mathrm{LiMn}_{2} \mathrm{O}_{4}(\mathbf{a})$ and $\mathrm{LiSi}_{0.05} \mathrm{Mn}_{1.95} \mathrm{O}_{4}$ (b) samples at a scan rate of $0.15 \mathrm{mV} \mathrm{s}^{-1}$; Nyquist plots of the $\mathrm{LiMn}_{2} \mathrm{O}_{4}$ (c) and $\mathrm{LiSi}_{0.05} \mathrm{Mn}_{1.95} \mathrm{O}_{4}$ (d) samples before cycling and after 100 cycles.

Figure 7c,d show the Nyquist plots of the undoped $\mathrm{LiMn}_{2} \mathrm{O}_{4}$ and the $\mathrm{LiMn}_{1.95} \mathrm{Si}_{0.05} \mathrm{O}_{4}$ samples. According to the reported results $[9,19]$, the charge transfer resistance $\left(\mathrm{R}_{2}\right)$ corresponding to the high-frequency semicircle has much to do with cycling life. Therefore, the influence of introducing some silicon ions on the cycling life was studied by a thorough analysis of $R_{2}$ values. Table 2 lists the relevant fitting values of $R_{2}$. For the Si-doped spinel, the original $R_{2}$ value only reached $61.5 \Omega \mathrm{cm}^{2}$ and increased to $90.6 \Omega \mathrm{cm}^{2}$ with a low growth rate of $47.3 \%$ after 100 cycles. Compared with the Si-doped spinel, the undoped spinel presents a higher original $R_{2}$ value $\left(92.3 \Omega \cdot \mathrm{cm}^{2}\right)$. After 100 cycles, this value could reach up to $302.7 \Omega \cdot \mathrm{cm}^{2}$ with a very high growth rate of $228.0 \%$. These analyses indicate that introducing some silicon ions can help to decrease the $\mathrm{R}_{2}$ value, which can promote lithium ion diffusion [18].

Table 2. Fitting values of the charge transfer resistance $\left(\mathrm{R}_{2}\right)$ calculated from EIS.

\begin{tabular}{cccc}
\hline Sample & $\begin{array}{c}\mathbf{R}_{\mathbf{2}}\left(\mathbf{\Omega} \cdot \mathrm{cm}^{\mathbf{2}}\right) \text { Before } \\
\text { Cycles }\end{array}$ & $\begin{array}{c}\mathbf{R}_{\mathbf{2}}\left(\boldsymbol{\Omega} \cdot \mathbf{c m}^{\mathbf{2}}\right) \text { After } \\
\mathbf{1 0 0} \text { Cycles }\end{array}$ & Percentage of Increase \\
\hline $\mathrm{LiMn}_{2} \mathrm{O}_{4}$ & 92.3 & 302.7 & $228.0 \%$ \\
$\mathrm{LiSi}_{0.05} \mathrm{Mn}_{1.95} \mathrm{O}_{4}$ & 61.5 & 90.6 & $47.3 \%$ \\
\hline
\end{tabular}

\section{Conclusions}

Silicon-doped lithium manganese oxides were obtained via a sol-gel process. As the optimal Si-doped spinel, the $\mathrm{LiSi}_{0.05} \mathrm{Mn}_{1.95} \mathrm{O}_{4}$ sample possessed a regular surface morphology and an even 
size distribution. More importantly, it showed much better electrochemical properties than those of the other Si-doped $\mathrm{LiMn}_{2} \mathrm{O}_{4}$ samples with a small amount of $\mathrm{Si}^{4+}$ ions. When cycled at $0.2{ }^{\circ} \mathrm{C}$ and $0.5^{\circ} \mathrm{C}$, the $\mathrm{LiMn}_{1.95} \mathrm{Si}_{0.05} \mathrm{O}_{4}$ sample exhibited 142.5 and $140.8 \mathrm{mAh} \cdot \mathrm{g}^{-1}$, respectively, which are higher values than those of the $\mathrm{LiMn}_{2} \mathrm{O}_{4}, \mathrm{LiMn}_{1.975} \mathrm{Si}_{0.025} \mathrm{O}_{4}$ and $\mathrm{LiMn}_{1.925} \mathrm{Si}_{0.075} \mathrm{O}_{4}$ samples. After 100 cycles, the $\mathrm{LiMn}_{1.95} \mathrm{Si}_{0.05} \mathrm{O}_{4}$ sample could exhibit $128.3 \mathrm{mAh} \cdot \mathrm{g}^{-1}$ with an outstanding retention of $91.1 \%$ at $0.5 \mathrm{C}$. When cycled at $10^{\circ} \mathrm{C}$, the initial discharge capacity of the optimal Si-doped $\mathrm{LiMn}_{2} \mathrm{O}_{4}$ sample could exhibit $88.3 \mathrm{mAh} \cdot \mathrm{g}^{-1}$. All of these results suggest that the optimal Si-doping amount can produce the best improvement effect on the electrochemical performance on the premise that all the silicon-doped spinels involved a small amount of $\mathrm{Si}^{4+}$ ions.

Author Contributions: H.Z., G.W. and J.S. conceived and designed the experiments; H.Z., D.L. and Y.W. performed the experiments; all authors analyzed the data; H.Z. wrote the paper; all authors discussed the results and commented on the paper.

Funding: This research was funded by the Landmark Innovation Project of Henan Institute of Science and Technology (No. 203010916004), High-level Talents Introduction Project of Henan Institute of Science and Technology (No. 203010617010 and No. 203010617011) and Key Research Project of Education Department of Henan Province (No. 19A150023).

Conflicts of Interest: The authors declare no conflict of interest.

\section{References}

1. Blomgren, G.E. The development and future of lithium ion batteries. J. Electrochem. Soc. 2016, 164, A5019-A5025. [CrossRef]

2. Zhao, H.; Chen, B.; Cheng, C.; Xiong, W.; Wang, Z.; Zhang, Z.; Wang, L.; Liu, X. A simple and facile one-step strategy to synthesize orthorhombic $\mathrm{LiMnO}_{2}$ nano-particles with excellent electrochemical performance. Ceram. Int. 2015, 41, 15266-15271. [CrossRef]

3. Hu, Y.; Zhao, H.; Liu, X. A simple, quick and eco-friendly strategy of synthesis nanosized $\alpha-\mathrm{LiFeO}_{2}$ cathode with excellent electrochemical performance for lithium-ion batteries. Materials 2018, 11. [CrossRef] [PubMed]

4. Put, B.; Vereecken, P.M.; Labyedh, N.; Sepulveda, A.; Huyghebaert, C.; Radu, I.P.; Stesmans, A. High cycling stability and extreme rate performance in nanoscaled $\mathrm{LiMn}_{2} \mathrm{O}_{4}$ thin films. ACS Appl. Mater. Interfaces 2015, 7, 22413-22420. [CrossRef] [PubMed]

5. Zhao, H.; Liu, S.; Cai, Y.; Wang, Z.; Tan, M.; Liu, X. A simple and mass production preferred solid-state procedure to prepare the $\mathrm{LiSi}_{\mathrm{x}} \mathrm{Mg}_{\mathrm{x}} \mathrm{Mn}_{2-2 \mathrm{x}} \mathrm{O}_{4}(0 \leq \mathrm{x} \leq 0.10)$ with enhanced cycling stability and rate capability. J. Alloys Compd. 2016, 671, 304-311. [CrossRef]

6. Liu, W.W.; Wang, D.; Wang, Z.; Deng, J.; Lau, W.M.; Zhang, Y. Influence of magnetic ordering and Jahn-teller distortion on the lithiation process of $\mathrm{LiMn}_{2} \mathrm{O}_{4}$. Phys. Chem. Chem. Phys. PCCP 2017, 19, 6481-6486. [CrossRef] [PubMed]

7. Shang, Y.; Lin, X.; Lu, X.; Huang, T.; Yu, A. Nano-TiO 2 (b) coated $\mathrm{LiMn}_{2} \mathrm{O}_{4}$ as cathode materials for lithium-ion batteries at elevated temperatures. Electrochim. Acta 2015, 156, 121-126. [CrossRef]

8. Zhang, X.; Xu, Y.; Zhang, H.; Zhao, C.; Qian, X. Structure and cycle stability of $\mathrm{SrHPO}_{4}$-coated $\mathrm{LiMn}_{2} \mathrm{O}_{4}$ cathode materials for lithium-ion batteries. Electrochim. Acta 2014, 145, 201-208. [CrossRef]

9. Zhao, H.; Li, F.; Liu, X.; Xiong, W.; Chen, B.; Shao, H.; Que, D.; Zhang, Z.; Wu, Y. A simple, low-cost and eco-friendly approach to synthesize single-crystalline $\mathrm{LiMn}_{2} \mathrm{O}_{4}$ nanorods with high electrochemical performance for lithium-ion batteries. Electrochim. Acta 2015, 166, 124-133. [CrossRef]

10. Lu, J.; Fan, X.; Zhou, C.; Liu, Z.; Zheng, F.; Lee, K.S.; Lu, L. Synergistic effect for $\mathrm{LiMn}_{2} \mathrm{O}_{4}$ microcubes with enhanced rate capability and excellent cycle stability for lithium ion batteries. J. Electrochem. Soc. 2015, 163, A197-A202. [CrossRef]

11. Huang, J.; Yang, F.; Guo, Y.; Peng, C.; Bai, H.; Peng, J.; Guo, J. LiMg $\mathrm{Mn}_{2-\mathrm{x}} \mathrm{O}_{4}(\mathrm{x} \leq 0.10)$ cathode materials with high rate performance prepared by molten-salt combustion at low temperature. Ceram. Int. 2015, 41, 9662-9667. [CrossRef]

12. Feng, X.; Zhang, J.; Yin, L. Enhanced cycling stability of $\mathrm{Co}_{3}\left(\mathrm{PO}_{4}\right)_{2}$-coated $\mathrm{LiMn}_{2} \mathrm{O}_{4}$ cathode materials for lithium ion batteries. Powder Technol. 2016, 287, 77-81. [CrossRef]

13. Deng, J.; Pan, J.; Yao, Q.; Wang, Z.; Zhou, H.; Rao, G. Porous core-shell $\mathrm{LiMn}_{2} \mathrm{O}_{4}$ microellipsoids as high-performance cathode materials for Li-ion batteries. J. Power Sources 2015, 278, 370-374. [CrossRef] 
14. Chen, Y.; Xie, K.; Pan, Y.; Zheng, C. Nano-sized $\mathrm{LiMn}_{2} \mathrm{O}_{4}$ spinel cathode materials exhibiting high rate discharge capability for lithium-ion batteries. J. Power Sources 2011, 196, 6493-6497. [CrossRef]

15. Li, Q.L.; Xu, W.Q.; Bai, H.L.; Guo, J.M.; Su, C.W. ZnO-coated $\mathrm{LiMn}_{2} \mathrm{O}_{4}$ cathode material for lithium-ion batteries synthesized by a combustion method. Ionics 2016, 22, 1343-1351. [CrossRef]

16. Prabu, M.; Reddy, M.V.; Selvasekarapandian, S.; Subba Rao, G.V.; Chowdari, B.V.R. (Li, Al)-co-doped spinel, $\mathrm{Li}\left(\mathrm{Li}_{0.1} \mathrm{Al}_{0.1} \mathrm{Mn}_{1.8}\right) \mathrm{O}_{4}$ as high performance cathode for lithium ion batteries. Electrochim. Acta 2013, 88, 745-755. [CrossRef]

17. Yu, F.D.; Wang, Z.B.; Chen, F.; Wu, J.; Zhang, X.-G.; Gu, D.M. Crystal structure and multicomponent effects in $\mathrm{Li}_{1+x} \mathrm{Mn}_{2-x-y} \mathrm{Al}_{\mathrm{y}} \mathrm{O}_{4}$ cathode materials for Li-ion batteries. J. Power Sources 2014, 262, 104-111. [CrossRef]

18. Xu, W.; Li, Q.; Guo, J.; Bai, H.; Su, C.W.; Ruan, R.; Peng, J. Electrochemical evaluation of $\mathrm{LiZn}_{\mathrm{x}} \mathrm{Mn}_{2-\mathrm{x}} \mathrm{O}_{4}$ $(\mathrm{x} \leq 0.10)$ cathode material synthesized by solution combustion method. Ceram. Int. 2016, 42, 5693-5698. [CrossRef]

19. Yi, X.; Wang, X.; Ju, B.; Wei, Q.; Yang, X.; Zou, G.; Shu, H.; Hu, L. Elevated temperature cyclic performance of $\mathrm{LiAl}_{\mathrm{x}} \mathrm{Mn}_{2-\mathrm{x}} \mathrm{O}_{4}$ microspheres synthesized via co-precipitation route. J. Alloys Compd. 2014, 604, 50-56. [CrossRef]

20. Mandal, S.; Rojas, R.M.; Amarilla, J.M.; Calle, P.; Kosova, N.V.; Anufrienko, V.F.; Rojo, J.M. High temperature Co-doped $\mathrm{LiMn}_{2} \mathrm{O}_{4}$-based spinels. Structural, electrical, and electrochemical characterization. Chem. Mater. 2002, 14, 1598-1605. [CrossRef]

21. Peng, Z.D.; Jiang, Q.L.; Du, K.; Wang, W.G.; Hu, G.R.; Liu, Y.X. Effect of Cr-sources on performance of $\mathrm{Li}_{1.05} \mathrm{Cr}_{0.04} \mathrm{Mn}_{1.96} \mathrm{O}_{4}$ cathode materials prepared by slurry spray drying method. J. Alloys Compd. 2010, 493, 640-644. [CrossRef]

22. Wang, J.L.; Li, Z.H.; Yang, J.; Tang, J.J.; Yu, J.J.; Nie, W.B.; Lei, G.T.; Xiao, Q.Z. Effect of Al-doping on the electrochemical properties of a three-dimensionally porous lithium manganese oxide for lithium-ion batteries. Electrochim. Acta 2012, 75, 115-122. [CrossRef]

23. Xiong, L.; Xu, Y.; Zhang, C.; Zhang, Z.; Li, J. Electrochemical properties of tetravalent Ti-doped spinel $\mathrm{LiMn}_{2} \mathrm{O}_{4}$. J. Solid State Electrochem. 2010, 15, 1263-1269. [CrossRef]

24. Iturrondobeitia, A.; Goñi, A.; Palomares, V.; Gil de Muro, I.; Lezama, L.; Rojo, T. Effect of doping $\mathrm{LiMn}_{2} \mathrm{O}_{4}$ spinel with a tetravalent species such as $\mathrm{Si}(\mathrm{iv})$ versus with a trivalent species such as Ga(iii). Electrochemical, magnetic and esr study. J. Power Sources 2012, 216, 482-488. [CrossRef]

25. Zhao, H.; Li, F.; Liu, X.; Cheng, C.; Zhang, Z.; Wu, Y.; Xiong, W.; Chen, B. Effects of equimolar Mg (ii) and $\mathrm{Si}$ (iv) co-doping on the electrochemical properties of spinel $\mathrm{LiMn}_{2-2 x} \mathrm{Mg}_{x} \mathrm{Si}_{x} \mathrm{O}_{4}$ prepared by citric acid assisted sol-gel method. Electrochim. Acta 2015, 151, 263-269. [CrossRef]

26. Xiong, L.; Xu, Y.; Tao, T.; Goodenough, J.B. Synthesis and electrochemical characterization of multi-cations doped spinel $\mathrm{LiMn}_{2} \mathrm{O}_{4}$ used for lithium ion batteries. J. Power Sources 2012, 199, 214-219. [CrossRef]

27. Guo, D.; Li, B.; Chang, Z.; Tang, H.; Xu, X.; Chang, K.; Shangguan, E.; Yuan, X.-Z.; Wang, H. Facile synthesis of $\mathrm{LiAl}_{0.1} \mathrm{Mn}_{1.9} \mathrm{O}_{4}$ as cathode material for lithium ion batteries: Towards rate and cycling capabilities at an elevated temperature. Electrochim. Acta 2014, 134, 338-346. [CrossRef]

28. Zhang, H.; Xu, Y.; Liu, D.; Zhang, X.; Zhao, C. Structure and performance of dual-doped $\mathrm{LiMn}_{2} \mathrm{O}_{4}$ cathode materials prepared via microwave synthesis method. Electrochim. Acta 2014, 125, 225-231. [CrossRef]

29. Xiang, M.; Su, C.W.; Feng, L.; Yuan, M.; Guo, J. Rapid synthesis of high-cycling performance $\operatorname{LiMg}_{\mathrm{x}} \mathrm{Mn}_{2-\mathrm{x}} \mathrm{O}_{4}$ $(\mathrm{x} \leq 0.20)$ cathode materials by a low-temperature solid-state combustion method. Electrochim. Acta 2014, 125, 524-529. [CrossRef]

30. Hao, J.; Bai, H.; Liu, J.; Yang, F.; Li, Q.; Su, C.; Guo, J. Synthesis and electrochemical properties of spinel $\mathrm{Li}\left(\mathrm{Li}_{0.05} \mathrm{Cu}_{0.05} \mathrm{Mn}_{1.90}\right) \mathrm{O}_{4}$ by a flameless combustion method. J. Alloys Compd. 2016, 668, 200-205. [CrossRef]

31. Zhao, H.; Liu, S.; Wang, Z.; Cai, Y.; Tan, M.; Liu, X. Enhanced elevated-temperature performance of $\mathrm{LiAl}_{\mathrm{x}} \mathrm{Si}_{0.05} \mathrm{Mg}_{0.05} \mathrm{Mn}_{1.90-\mathrm{x}} \mathrm{O}_{4}(0 \leq \mathrm{x} \leq 0.08)$ cathode materials for high-performance lithium-ion batteries. Electrochim. Acta 2016, 199, 18-26. [CrossRef]

32. Mohan, P.; Paruthimal Kalaignan, G. Structure and electrochemical performance of surface modified LaPO coated $\mathrm{LiMn}_{2} \mathrm{O}_{4}$ cathode materials for rechargeable lithium batteries. Ceram. Int. 2014, 40, 1415-1421. [CrossRef]

33. Wu, X.M.; Li, X.H.; Xiao, Z.B.; Liu, J.; Yan, W.B.; Ma, M.Y. Synthesis and characterization of $\operatorname{LiMn}_{2} \mathrm{O}_{4}$ powders by the combustion-assisted sol-gel technique. Mater. Chem. Phys. 2004, 84, 182-186. [CrossRef] 
34. Li, Z.; Yang, J.; Wang, J.; Tang, J.; Lei, G.; Xiao, Q. A phase-inversion process to prepare porous $\mathrm{LiAl}_{0.1} \mathrm{Mn}_{1.9} \mathrm{O}_{4}$ spinel for aqueous rechargeable lithium batteries. Microporous Mesoporous Mater. 2012, 162, 44-50. [CrossRef]

35. Karthick, S.N.; Richard Prabhu Gnanakan, S.; Subramania, A.; Kim, H.-J. Nanocrystalline $\mathrm{LiMn}_{2} \mathrm{O}_{4}$ thin film cathode material prepared by polymer spray pyrolysis method for li-ion battery. J. Alloys Compd. 2010, 489, 674-677. [CrossRef] 